\title{
Nutrition of Flavobacterium aquatile Strain Taylor and a Microbiological Assay for Thiamine
}

\author{
By O. B. WEEKS AND S. M. BECK \\ Department of Bacteriology, University of Idaho, Moscoro, Idaho, U.S.A.
}

(Received 27 February 1960)

\begin{abstract}
SUMMARY
Flavobacterium aquatile strain Taylor grew readily in a medium containing ( $\%, w / v)$; trypticase, 0.5 ; glucose, $0.5 ; \mathrm{K}_{2} \mathrm{HPO}_{4}, 0.05 ; \mathrm{KH}_{2} \mathrm{PO}_{4}, 0.05 ; \mathrm{MgSO}_{4} .7 \mathrm{H}_{2} \mathrm{O}, 0.02$; supplemental thiamine. Growth was proportional to the thiamine-HCl content in the range $1-80 \mathrm{~m} \mu \mathrm{g} . / 10 \mathrm{ml}$. medium. Larger quantities of thiamine did not increase growth. Maximum growth responses at all concentrations of thiamine were obtained after $48 \mathrm{hr}$. incubation at $30^{\circ}$ when the cultures were shaken during incubation. The response of $\boldsymbol{F}$. aquatile to thiamine gives a basis for a microbiological assay. Of the compounds tested only thiamine pyrophosphate and acetylthiamine replaced thiamine. None of the other vitamins, or various purines, pyrimidines, nucleosides, or miscellaneous compounds tested except certain carbohydrates, altered the response to thiamine. Maltose or ribose $(0.5 \%, \mathrm{w} / \mathrm{v})$ stimulated $F$. aquatile in the range $0-5 \mathrm{~m} \mu \mathrm{g}$. thiamine $/ 10 \mathrm{ml}$. At greater concentrations of thiamine, and in the presence of glucose, slight growth inhibitions were caused by maltose and ribose. Sodium chloride at concentrations greater than $0.05 \mathrm{M}$ retarded growth generally and therefore the response to thiamine was modified. None of the interfering compounds appeared to invalidate the use of the bacterium as an assay organism for thiamine.
\end{abstract}

\section{INTRODUCTION}

The measurement of thiamine in natural materials may be accomplished by chemical or biological methods, the latter being especially useful where small amounts of the vitamin are concerned. Techniques which have been proposed were reviewed by Mickelsen \& Yamamoto (1958). In addition Deibel, Evans \& Niven (1957) described a procedure using Lactobacillus viridescens; Maciasr (1957) reported an improved assay medium for use with $L$. fermenti; and Littman (1958) showed that the pathogen Cryptococcus neoformans could be used for thiamine assay. Of the several micro-organisms proposed, L. fermenti (Sarett \& Cheldelin, 1944), Kloeckera brevis (Hoff-Jorgensen \& Hansen, 1955) and L. viridescens (Deibel et al. 1957) seem best suited for routine assay. With the exception of mutant strains of Escherichia coli (Mickelsen \& Yamamoto, 1958) the use of Gram-negative bacteria for such an assay has not been common. Investigations of the nutritional requirements of Flavobacterium aquatile strain Taylor (Lauro, 1955) showed a requirement for thiamine in a relatively simple basal medium. That study has been continued and a microbiological assay for thiamine dependent upon the growth of $F$. aquatile is presented here. 


\section{METHODS}

Organism. Flavobacterium aquatile strain Taylor was originally obtained from Dr E. Windle Taylor (London) who made the isolation from the source described by Frankland \& Frankland (1889) for Bacillus aquatilis. The strain has been studied (Weeks, 1955) but a detailed report of its nutritional requirements has not been made. The bacterium has been placed in several culture collections: the National collection of Type Cultures, London; the Northern Regional Research Laboratories, U.S. Department of Agriculture, Peoria, Illinois; the American Type Culture Collection, Washington, D.C.

Media. Stock cultures were maintained upon slopes of medium M-5 agar containing $(\%, \mathrm{w} / \mathrm{v})$ : Difco sodium caseinate, 0.2; Difco yeast extract, 0.05; Difco proteose peptone, $0.05 ; \mathrm{K}_{2} \mathrm{HPO}_{4}, 0.05$; agar, $1 \cdot 5$; adjusted to $\mathrm{pH} 7 \cdot 4-7 \cdot 6$. All media were prepared with twice-distilled water. The studies of the growth response to thiamine were made in tubes containing $10 \mathrm{ml}$. liquid medium (A-1) of the following (final) composition ( $\%, w / v): \mathrm{K}_{2} \mathrm{HPO}_{4}, 0.05 ; \mathrm{KH}_{2} \mathrm{PO}_{4}, 0.05 ; \mathrm{MgSO}_{4} .7 \mathrm{H}_{2} \mathrm{O}$, 0.02; glucose, 0.5; trypticase (a tryptic digest of casein; Baltimore Biological Laboratories), 0.5. A solution of the inorganic salts was prepared separately, adjusted to $\mathrm{pH} 7 \cdot 4$, and autoclaved $\left(121^{\circ}, 15 \mathrm{~min}\right.$.). The volume of water used in preparing the salt solution was between 50 and $90 \%(v / v)$ of the ultimate volume, depending on the experiment. The glucose and trypticase were added aseptically to the salt solution in $0.5 \mathrm{ml}$. amounts from separately sterilized $10 \%(\mathrm{w} / \mathrm{v})$ stock solutions. Sterile solutions of thiamine and the various organic supplements being considered were then added, and finally the volume brought up to $10 \mathrm{ml}$. per tube with sterile water. After the composition of the assay medium was established, aseptic assembling of the medium was given up for conventional preparation and autoclave sterilization of the complete medium, except for thiamine or the samples being assayed. These latter were always added aseptically from sterile solutions. Usually bromthymol blue indicator was included in medium A-1. When any of the aseptic supplementations changed the $\mathrm{pH}$ value as shown by the indicator, the reaction was readjusted with sterile $2 \%(\mathrm{w} / \mathrm{v}) \mathrm{HCl}$ or $\mathrm{NaOH}$ solution.

Preparation of inoculum. Stock cultures of Flavobacterium aquatile growing upon M-5 agar slopes were subcultured every two weeks. Following inoculation, the cultures were incubated at $28-30^{\circ}$ for $48 \mathrm{hr}$. and then stored at $10^{\circ}$. Cultures to be used for studies of growth response to thiamine were also grown upon M-5 agar medium. A $24 \mathrm{hr}$. stock culture was used to inoculate a sufficient number of slopes for an experiment. After 24 hr. incubation, the growth was suspended in sterile distilled water, adjusted to a standardized turbidity (optical density $=c$. $0 \cdot 25$, light path $=1 \mathrm{~cm}$., $\lambda=550 \mathrm{~m} \mu$ ), and $0.1 \mathrm{ml}$. used to inoculate each tube.

Culture conditions. All studies of the nutritional requirements of Flavobacterium aquatile were done in test tubes $(19 \times 150 \mathrm{~mm}$.) covered with Morton stainlesssteel culture tube closures (Bellco Glass, Inc., Vineland, N.J.). The tubes were incubated at $28-30^{\circ}$ on a rotary shaker adjusted to give $160 \mathrm{rev} . / \mathrm{min}$. Incubation times were 24-96 hr., depending upon the experiment.

Measurement of growth. The relative extent of bacterial growth was estimated from turbidity read as optical density on a Beckman Model B spectrophotometer set at a wavelength of $550 \mathrm{~m} \mu$. When the medium included bromthymol blue indi- 
cator, all tubes were acidified $(0 \cdot 1 \mathrm{ml}$. of $\mathrm{N}-\mathrm{HCl})$ before measurement of optical density. The cultures were poured into $1 \mathrm{~cm}$. cuvettes (Corex) and the optical measurements were made by using the uninoculated medium as the reference.

\section{RESULTS}

\section{Inorganic salts solution}

Investigations of the response of Flavobacterium aquatile to thiamine were begun with the inorganic salt solutions A and C of Snell \& Wright (1941). This mixture was supplemented with stock solutions of glucose and trypticase to $0.5 \%(\mathrm{w} / \mathrm{v})$ of each and with $10 \mu \mathrm{g}$. thiamine. $\mathrm{HCl} / \mathrm{tube}$. The complete medium contained $0.5 \mathrm{ml}$. each of stock solutions $A$ and $C$ per $100 \mathrm{ml}$. The inorganic compounds of the salt solutions (Table 1 ) were tested in several mixtures to determine the minimal mixture necessary. The results (Table 1; Fig. 1) showed that a mixture of the potassium phosphates and magnesium sulphate or the complete $\mathbf{A}$ and $\mathbf{C}$ mixture was required for maximum growth. The mixture of potassium phosphates and magnesium sulphate was chosen for subsequent experiments. The apparent inhibition by manganese and iron salts was not studied further.

Table 1. Effect of inorganic salts upon the growth of Flavobacterium aquatile

\begin{tabular}{|c|c|}
\hline Inorganic constituents* & $\begin{array}{l}\text { Growth after } \\
\text { supplementation } \\
\text { with organic } \\
\text { compounds } \dagger \\
\text { (optical density) }\end{array}$ \\
\hline $\mathrm{A}+\mathrm{C}$ & $2 \cdot 09$ \\
\hline A & $1 \cdot 64$ \\
\hline $\mathrm{C}$ & $1 \cdot 36$ \\
\hline $\mathrm{A}+\mathrm{MgSO}_{4} \cdot 7 \mathrm{H}_{2} \mathrm{O}$ & $2 \cdot 00$ \\
\hline $\mathrm{A}+\mathrm{NaCl}$ & 1.66 \\
\hline $\mathrm{A}+\mathrm{MnSO}_{4} \cdot \mathrm{H}_{2} \mathrm{O}$ & 0.64 \\
\hline $\mathrm{A}+\mathrm{FeSO}_{4} \cdot 7 \mathrm{H}_{2} \mathrm{O}$ & 0.97 \\
\hline None & $1 \cdot 40$ \\
\hline
\end{tabular}

* A contained (mg./10 ml. medium) $\mathrm{K}_{2} \mathrm{HPO}_{4}, 5 \cdot 0 ; \mathrm{KH}_{2} \mathrm{PO}_{4}, 5.0 . \mathrm{C}$ contained (mg. $/ 10 \mathrm{ml}$. medium) $\mathrm{MgSO}_{4} .7 \mathrm{H}_{2} \mathrm{O}, 4 \cdot 0 ; \mathrm{NaCl}, 0.2 ; \mathrm{MnSO}_{4} . \mathrm{H}_{2} \mathrm{O}, 0.8 ; \mathrm{FeSO}_{4} .7 \mathrm{H}_{2} \mathrm{O}, 0.02$. Single inorganic salts were used in same concentration in which they were found in $\mathrm{C}$.

$\dagger$ Organic supplements (amt./10 ml. medium) were: trypticase, $50 \mathrm{mg}$; glucose, $50 \mathrm{mg}$.; thiamine. $\mathrm{HCl}, 10 \mu \mathrm{g}$. Cultures were incubated at $30^{\circ}$ for $48 \mathrm{hr}$. with continuous shaking.

\section{Nitrogen source}

Preliminary studies showed that neither various amino acid mixtures, nor acid-hydrolysed casein served as the nitrogen source. Various enzymic hydrolysates of casein were satisfactory; trypticase was chosen. Addition of glucose greatly increased the growth (Fig. 5). Within the first $48 \mathrm{hr}$. of incubation the optimal concentration of trypticase was $0.5 \%(\mathrm{w} / \mathrm{v})$. Trypticase at $1 \%(\mathrm{w} / \mathrm{v})$ markedly delayed growth during the initial $48 \mathrm{hr}$. of incubation, but this retardation disappeared by $96 \mathrm{hr}$. (Fig. 1). The reason for this retardation of growth at the higher peptone concentrations is not known, but it was found that after dialysis of the trypticase, the non-diffusible fraction did not show growth retardation at con- 
centrations equivalent to $1 \%$ trypticase (Fig. 1c). Flame photometric analysis (Perkins Elmer flame photometer) showed trypticase to contain sodium equivalent to $0 \cdot 70 \% \mathrm{NaCl}$ and potassium equivalent to $0 \cdot 36 \% \mathrm{KCl}$; total ash was $6-7 \%$.

\section{Response of Flavobacterium aquatile to thiamine}

The growth response of Flavobacterium aquatile to thiamine in medium A-1 is shown in Fig. 2, upper curve. Thiamine was added aseptically to each tube as a sterile dilution prepared from a thiamine. $\mathrm{HCl}$ stock solution (10 mg./100 ml.). The stock solution was autoclaved for $10 \mathrm{~min}$. at $121^{\circ}$. It was unnecessary to acidify the solution to prevent thiamine destruction during sterilization. Amounts of

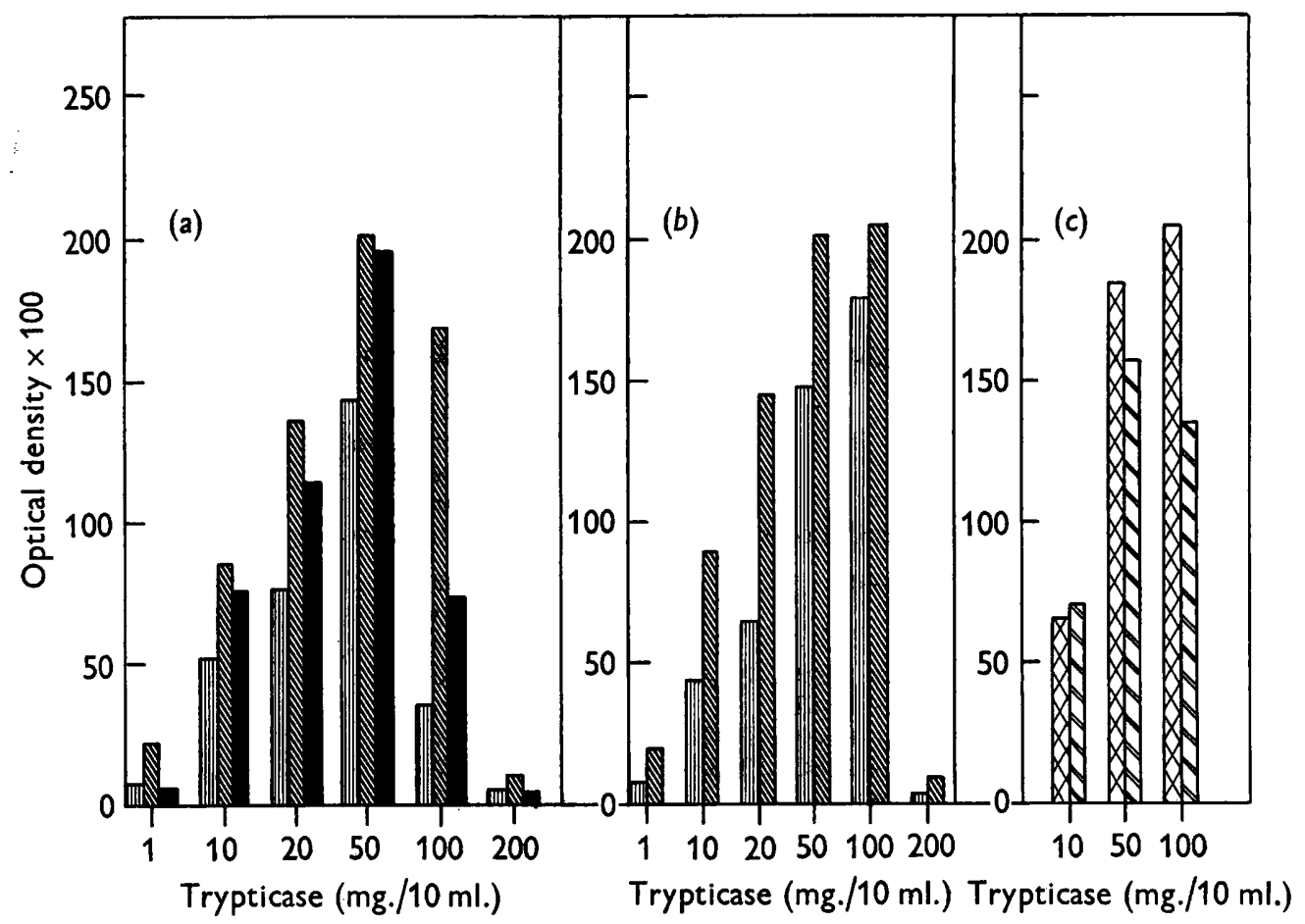

Fig. 1. Effect of trypticase content and inorganic basal medium composition on the growth of Flavobacterium aquatile. All media contained $0.5 \%(\mathrm{w} / \mathrm{v})$ glucose and $10 \mu \mathrm{g}$.

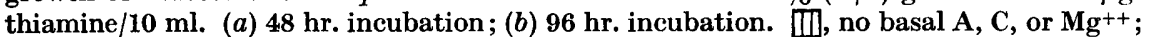

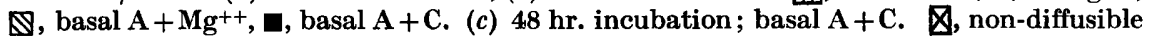
trypticase fraction; $\mathbb{S}$, diffusate trypticase fraction.

thiamine. $\mathrm{HCl}$ from $0 \cdot 1$ to $10,000 \mathrm{~m} \mu \mathrm{g} . / 10 \mathrm{ml}$. medium were tested. Quantitative responses to thiamine. $\mathrm{HCl}$ occurred in the range from 1 to $50 \mathrm{~m} \mu \mathrm{g} . / 10 \mathrm{ml}$. Maximum growth occurred when $80 \mathrm{~m} \mu \mathrm{g}$. of the vitamin were present, and increasing the concentration to $10,000 \mathrm{~m} \mu \mathrm{g}$. did not further increase growth. Between 50 and $80 \mathrm{~m} \mu \mathrm{g} . / 10 \mathrm{ml}$. the rate of growth progressively decreased and the accuracy of the assay decreased. Although growth responses were apparent in the range of $0 \cdot 1-$ $1.0 \mathrm{~m} \mu \mathrm{g} . / 10 \mathrm{ml}$., the accuracy of the assay may be questioned at these lower concentrations. The shape of the thiamine response curve has remained unchanged 
during a year or more of study. The maximum growth response to thiamine was obtained within $48 \mathrm{hr}$; the optical density was unchanged by further incubation. For thiamine. $\mathrm{HCl}$ concentrations greater than $10 \mathrm{~m} \mu \mathrm{g} . / \mathrm{ml}$., maximum growth did not occur within the initial $24 \mathrm{hr}$. of incubation (Table 2).

Table 2. Influence of incubation time upon the groroth response of Flavobacterium aquatile to thiamine in medium $A-1$

\begin{tabular}{|c|c|c|c|c|}
\hline \multirow[b]{2}{*}{$\begin{array}{c}\text { Thiamine } \\
\text { HCl } \\
\text { (m } \mu \mathrm{g} .110 \mathrm{ml} .)\end{array}$} & \multicolumn{4}{|c|}{ Incubation time } \\
\hline & $24 \mathrm{hr}$. & $\begin{array}{r}48 \mathrm{hr} . \\
\text { Growth at } 30^{\circ}\end{array}$ & $\begin{array}{l}72 \text { hr. } \\
\text { density }\end{array}$ & $96 \mathrm{hr}$. \\
\hline 100 & 46 & 192 & - & 198 \\
\hline $\mathbf{5 0}$ & $\mathbf{5 2}$ & 167 & 146 & 159 \\
\hline 30 & - & 152 & 149 & 159 \\
\hline 10 & 29 & 56 & $\mathbf{5 1}$ & 54 \\
\hline 6 & 43 & 35 & 36 & 40 \\
\hline 4 & 27 & 27 & 28 & 36 \\
\hline 1 & 17 & 16 & 16 & 16 \\
\hline $0 \cdot 6$ & 10 & 11 & 13 & 13 \\
\hline 0.4 & 10 & 11 & 14 & 13 \\
\hline $0 \cdot 1$ & 10 & 13 & 12 & 11 \\
\hline $0 \cdot 0$ & 9 & 9 & 9 & - \\
\hline
\end{tabular}

\section{Influence of cultural history on the response of Flavobacterium aquatile to thiamine}

The growth response of Flavobacterium aquatile to thiamine was very stable. Shortly after the organism was isolated in 1952, a number of cultures were lyophilized. In addition, the parent culture and selections from platings of it were maintained as growing cultures. During a 5-year period, 9 separate clones have been maintained and all have responded similarly to thiamine. A lyophilized culture was activated, subcultured twice and then tested for its growth response to thiamine; the response was typical. One of the cultures had been given to a colleague who maintained it by infrequent subculture; this clone was tested and also gave a growth response to thiamine which was indistinguishable from that shown in Fig. 2, upper curve.

Inocula for the thiamine growth response studies were usually distilled water suspensions from M-5 agar slope cultures and were used without washing. In one group of experiments the inocula were washed with phosphate buffer, but the results were not different from those shown in Fig. 2, upper curve. The trace of growth in medium A-1 without added thiamine. HCl, was not decreased. When stock cultures were subcultured monthly and the growth from $24 \mathrm{hr}$. subcultures used to inoculate medium A-1, the maximum growth response was equivalent to optical density $c .1 \cdot 7$; with weekly or more frequent subcultures, the maximum growth increased to optical density $c .2 \cdot 3$. With the increase in optical density the slope of the growth response curve increased. 
The effect of sterilization of the assay medium on response of Flavobacterium aquatile to thiamine

Medium A-1 was usually prepared aseptically by mixing sterile stock solutions. Investigations were made of the growth responses of Flavobacterium aquatile to thiamine in the medium prepared in a variety of ways with respect to sterilization, to determine whether aseptic compounding was necessary. Results are shown in Fig. 2. A usable assay curve was obtained when the complete medium, except for thiamine, was autoclaved. It is evident that growth responses to thiamine were decreased when the assay medium was prepared in any manner other than assembly from separately sterilized stock solutions. The extreme decrease in growth response occurred when the vitamin was autoclaved with the medium and was doubtless due to partial destruction of the vitamin during sterilization.

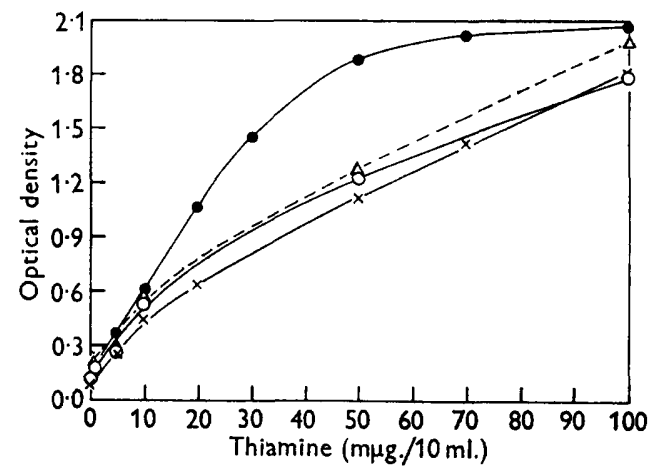

Fig. 2

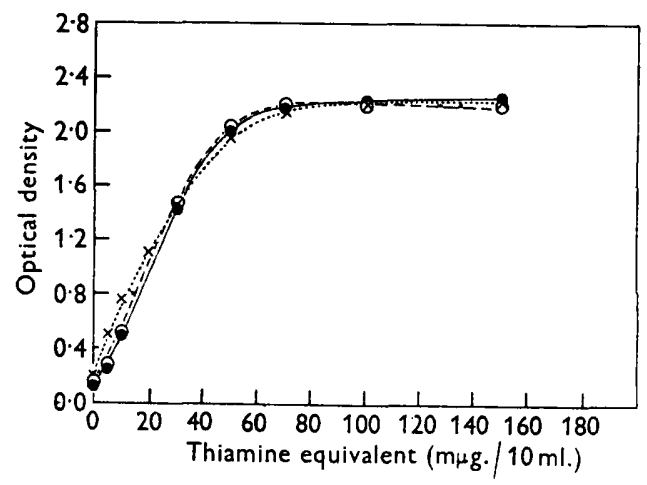

Fig. 3

Fig. 2. Effect on growth responses of Flavobacterium aquatile produced by autoclaving various mixtures of constituents of medium A-1. - - basal medium autoclaved; trypticase, glucose and thiamine added aseptically. $\Delta--\Delta$, basal medium + trypticase autoclaved together; glucose and thiamine added aseptically. $\mathrm{O}-\mathrm{O}$, basal medium + trypticase + glucose autoclaved together; thiamine added aseptically. $x-x$, basal medium + trypticase + glucose + thiamine autoclaved together.

Fig. 3. Growth responses of Flavobacterium aquatile to various forms of thiamine in medium A-1. $\times \cdots \times$, thiamine pyrophosphate; $\odot-\odot$, acetylthiamine; $-\bullet$, thiamine.

Studies suggested that some of the decreased response to thiamine in the autoclaved medium was associated with reactions involving trypticase rather than glucose. A general decrease in the growth response to thiamine occurred irrespective of whether or not glucose was included in the medium before autoclaving (Fig. 2). In a different experiment medium A-I was assembled from the previously sterilized stock solutions but the trypticase stock solutions had been heated for $2 \mathrm{hr}$. at $121^{\circ}$. The growth-response curve to thiamine resembled that which occurred when the inorganic salts solution and trypticase were autoclaved together. The decreases in growth response to thiamine were greater in the range 5-70 $\mathrm{m} \mu \mathrm{g} . / 10 \mathrm{ml}$. than for lesser or greater amounts of thiamine. The consequence of this was an almost $50 \%$ increase in the range of thiamine concentrations which could be measured from growth response. 


\section{The specificity of the requirement for thiamine}

Thiamine pyrophosphate or acetylthiamine replaced thiamine quantitatively in medium A-1 (Fig. 3). The two moieties of thiamine, namely 2-methyl-4-amino-5aminomethyl pyrimidine. $2 \mathrm{HCl}$ and 4-methyl-5- $\beta$-hydroxyethyl thiazole, singly or together, were unable to replace thiamine (Table 3).

The remaining organic compounds tested did not replace thiamine or affect growth in the presence of thiamine. The compounds tested and the concentrations used in medium A-1 are listed following. Purines and pyrimidines (100 $\mu \mathrm{g} . / 10 \mathrm{ml}$.): guanine, adenine, xanthine, hypoxanthine, 2:6-diaminopurine, cytosine, thymine, uracil, orotic acid, and the nucleoside thymidine. Vitamins of the B-complex (filtered sterile): folic acid, biotin, vitamin $B_{12}$, thioctic acid (1 or $10 \mathrm{~m} \mu \mathrm{g} . / 10 \mathrm{ml}$.); riboflavin-5-phosphate, riboflavin, calcium pantothenate, pyridoxal. $\mathrm{HCl}$, pyridoxal

Table 3. Growth of Flavobacterium aquatile in media containing thiamine or its moieties

Compound

\begin{tabular}{|c|c|c|c|c|c|c|c|}
\hline \multirow[t]{4}{*}{ Compound } & \multicolumn{7}{|c|}{ Concentrations used } \\
\hline & \multicolumn{7}{|c|}{ (m $\mu \mathrm{g} . / 10 \mathrm{ml})}$. \\
\hline & 100,000 & 100 & 50 & 10 & 5 & 1 & $\mathbf{0}$ \\
\hline & \multicolumn{7}{|c|}{ Growth (optical density $\times 100$ ) } \\
\hline Thiamine.HCl & 224 & 220 & 201 & $\mathbf{5 8}$ & 33 & 20 & 12 \\
\hline $\begin{array}{l}\text { 2-Methyl-4-amino-5-amino- } \\
\text { methyl pyrimidine.2HCl (A) }\end{array}$ & 11 & 11 & 11 & 11 & 11 & 10 & 9 \\
\hline $\begin{array}{l}\text { 4-Methyl-5- } \beta \text {-hydroxyethyl- } \\
\text { thiazole (B) }\end{array}$ & 9 & 9 & $\boldsymbol{9}$ & 10 & 12 & 9 & 10 \\
\hline$(A)+(B)$ & 9 & $\boldsymbol{9}$ & $\boldsymbol{9}$ & $\longrightarrow$ & 10 & 10 & 9 \\
\hline
\end{tabular}

Thiamine.HCl

2-Methyl-4-amino-5-amino-

methyl pyrimidine.2HCl (A)

4-Methyl-5- $\beta$-hydroxyethylthiazole (B)

(A) + (B)

phosphate, pyridoxamine. $2 \mathrm{HCl}$, pyridoxine. $\mathrm{HCl}$, nicotinamide, nicotinic acid, $p$-aminobenzoic acid, $p$-hydroxybenzoic acid, choline chloride $(10 \mathrm{~m} \mu \mathrm{g}$. or $10 \mu \mathrm{g}$./ $10 \mathrm{ml}$.); inositol (100 or $500 \mu \mathrm{g} . / 10 \mathrm{ml}$.). Mixtures of all of the purines and pyrimidines or all of the B-vitamins did not allow growth in the presence of thiamine or in its absence. Miscellaneous compounds: ureidosuccinic acid, kinetin, ascorbic acid, and sodium thioglycollate did not influence the response of the bacterium to thiamine.

Carbohydrates. The carbohydrates shown in Table 4 were tested for their effects upon the response of Flavobacterium aquatile to thiamine. The results show that fructose, maltose and the pentoses when added to the glucose + thiamine-containing medium increased bacterial growth beyond that of the glucose control. Similar effects were evident in the absence of glucose, except for arabinose. Ribose and maltose supported some growth in the absence of thiamine and this was studied more extensively.

The ribose and maltose effects were studied by adding $0.5 \%(\mathrm{w} / \mathrm{v})$ ribose or maltose to medium A-1, already containing $0.5 \%$ glucose, or by substituting ribose or maltose for the glucose. Influence of carbohydrate concentration per se was determined from growth responses in medium A-1 containing either no added carbohydrate, or 0.5 or $1.0 \%$ glucose. The results are shown in Figs. 4, 5. The mixtures of ribose + glucose or maltose + glucose increased growth beyond that of the 
Table 4. Influence of carbohydrates upon the response of Flavobacterium aquatile to thiamine in medium $A-1$

\begin{tabular}{|c|c|c|c|}
\hline & \multicolumn{2}{|c|}{ Thiamine present $\dagger$} & \multirow{2}{*}{$\begin{array}{l}\text { No thiamine } \\
\text { or glucose }\end{array}$} \\
\hline & Glucose & No glucose & \\
\hline & \multicolumn{3}{|c|}{ Growth response (optical density $\times 100$ ) } \\
\hline tardonyurale. & & & \\
\hline Xylose & 47 & 32 & 10 \\
\hline Arabinose & 44 & 13 & 8 \\
\hline Ribose & 124 & 94 & 62 \\
\hline Fructose & $\mathbf{5 8}$ & 24 & $\mathbf{9}$ \\
\hline Galactose & $\mathbf{3 7}$ & 15 & 7 \\
\hline Maltose & 168 & $\mathbf{5 2}$ & $\mathbf{2 3}$ \\
\hline Sucrose & 27 & $\boldsymbol{\theta}$ & 8 \\
\hline Lactose & 37 & 18 & 8 \\
\hline None & 40 & 18 & 8 \\
\hline
\end{tabular}

control when concentrations of thiamine. $\mathrm{HCl}$ were less than $10 \mathrm{~m} \mu \mathrm{g} . / 10 \mathrm{ml}$. (Fig. 4). With greater amounts of thiamine the growth was less than that of the glucose control. The slight stimulatory effects of ribose and maltose were apparent whether or not thiamine was added (Figs. 4, 5). The possibility that the ribose and

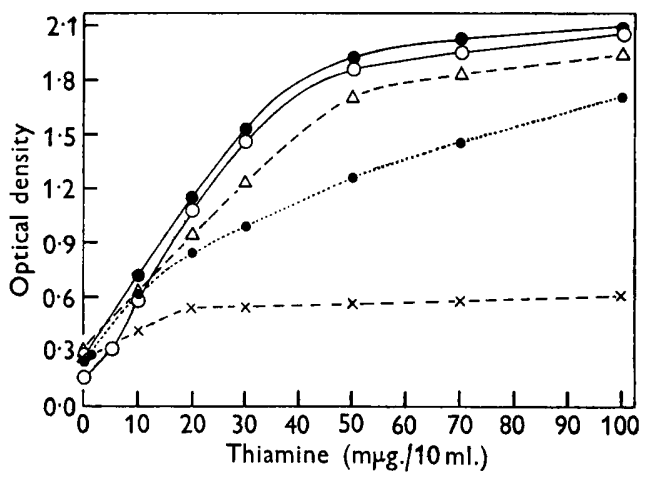

Fig. 4

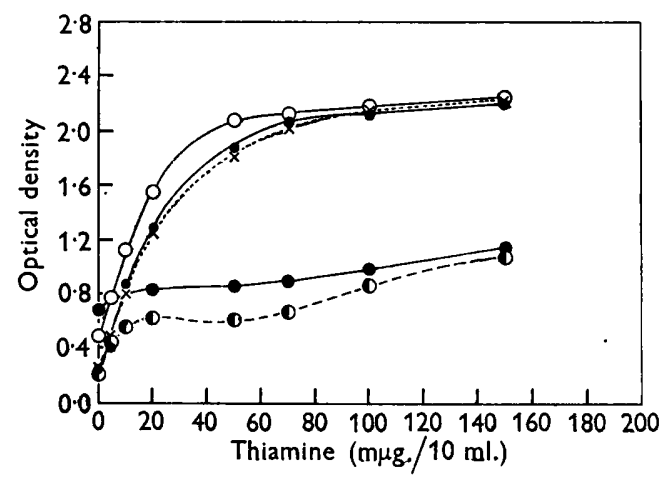

Fig. 5

Fig. 4. Effect of various carbohydrates on the growth response of Flavobacterium aquatile to thiamine. Systems contained basal medium $\mathbf{A}+\mathrm{Mg}^{++}, 0.5 \%(\mathrm{w} / \mathrm{v})$ trypticase, and $0.5 \%(w / v)$ of each carbohydrate as follows: - - maltose; $O-O$, glucose; $\triangle-\triangle$, glucose + ribose; $\bullet . . . \bullet$, glucose + maltose; $x-\times$, ribose. All supplements added aseptically from sterile stock solutions.

Fig. 5. Effect of various carbohydrates on the growth response of Flavobacterium aquatile to thiamine. All supplements added aseptically to basal medium $\mathbf{A}+\mathrm{Mg}^{++}$from sterile stock solutions. Systems contained $0.5 \%(\mathrm{w} / \mathrm{v})$ trypticase plus the following $\%(w / v)$ carbohydrates: $\bigcirc-\emptyset$, no added carbohydrate; $-\bullet, 0.5 \%$ ribose; $\bullet-$, $0.5 \%$ glucose ; $\times \cdots \times, 1.0 \%$ glucose; $\bigcirc-0,0.5 \%$ maltose.

maltose used were contaminated by minute amounts of thiamine was not excluded. Ribose seemed unavailable as an energy source but maltose was satisfactory. The mixtures glucose + maltose or glucose + ribose decreased the growth response to 
thiamine when compared with that which occurred in the medium containing only glucose. The reason for this is not known.

The principal problem, however, was to define the degree to which ribose and maltose would interfere with microbiological assays for thiamine when using medium A-1. Usually this medium was supplemented with different amounts of thiamine which were prepared from a sterile stock solution using water as the diluent. To study the effects of maltose and ribose as if these compounds were present in natural substances subjected to assay, the first $\mathbf{1 0}$-fold dilution of the stock thiamine. $\mathrm{HCl}(10 \mathrm{mg} . / 100 \mathrm{ml}$.) was made in $1 \%(\mathrm{w} / \mathrm{v})$ maltose or ribose solution; the subsequent dilutions were made with sterile water. In this manner, amounts of either carbohydrate (1-100 mg.) were added to each tube along with the thiamine; the results are shown in Fig. 6. It would seem that with the experimental conditions used, neither maltose nor ribose influenced the accuracy of the assay.

Influence of $\mathrm{NaCl}$. Flavobacterium aquatile appeared to be unusually sensitive to electrolytes; its sensitivity to $\mathrm{NaCl}$ is shown in Fig. 7. Under conditions allowing maximum growth $(0.5 \%, \mathrm{w} / \mathrm{v}$, trypticase) addition of $0 \cdot 2 \mathrm{M}-\mathrm{NaCl}$ essentially stopped

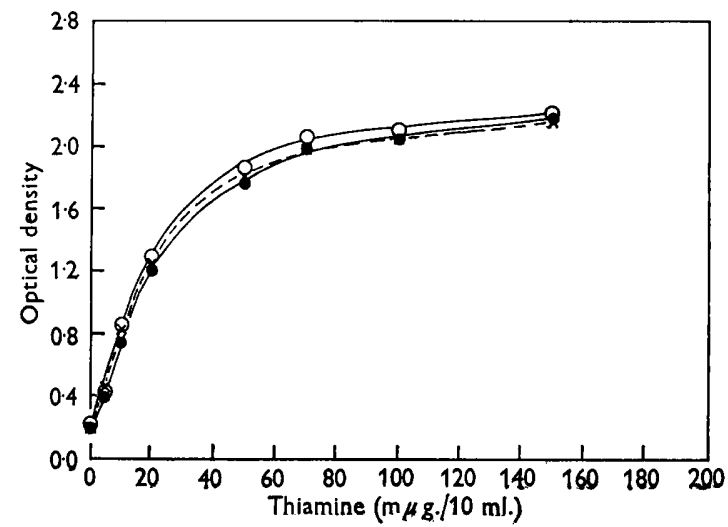

Fig. 6

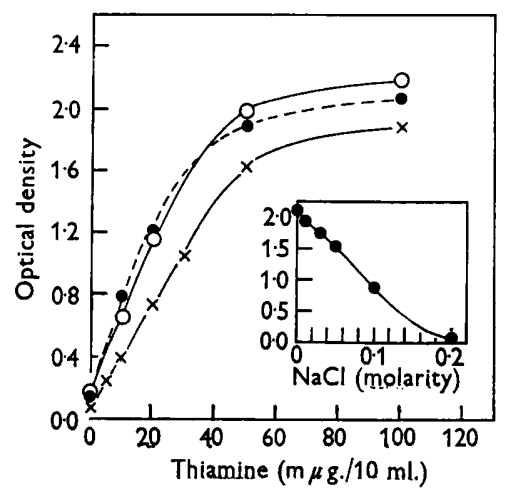

Fig. 7

Fig. 6. Effect of constant ribose:thiamine and maltose:thiamine ratios on the growth response of Flavobacterium aquatile. Stock thiamine solution contained $1.0 \mathrm{mg}$. thiamine/ $100 \mathrm{ml}$. of $1 \%$ ribose or maltose. Subsequent dilutions made with distilled water. All systems contained basal medium $\mathrm{A}+\mathrm{Mg}^{++}, \mathbf{0 . 5} \%$ trypticase, and $0.5 \%$ glucose $(\mathrm{w} / \mathrm{v})$. $\mathrm{O}-\mathrm{O}$, control (all thiamine dilutions in water); $\times--\times$, maltose added with thiamine; $-\bullet$ ribose added with thiamine.

Fig. 7. Growth response curves of Flavobacterium aquatile to thiamine in presence of different $\mathrm{NaCl}$ concentrations. Systems contained basal medium $\mathbf{A}+\mathbf{M g}^{++}, \mathbf{0 . 5} \%$ trypticase, $0.5 \%$ glucose $(\mathrm{w} / \mathrm{v})$, and the following molar concentrations of $\mathrm{NaCl}: \mathrm{O}-\mathrm{O}$, control (no $\mathrm{NaCl}$ ); --. $0.02 \mathrm{M}-\mathrm{NaCl} ; \times-\times, 0.05 \mathrm{M}-\mathrm{NaCl}$. Fig. 7 (inset) shows growth response of $F$. aquatile to thiamine in above control medium containing the indicated molar concentrations of $\mathrm{NaCl}$.

growth; perceptible inhibition occurred in media containing $0.01 \mathrm{M}-\mathrm{NaCl}$. This inhibitory effect was more pronounced with smaller concentrations of trypticase. Sodium chloride was not a specific inhibitor; similar results in different degrees were obtained with $\mathrm{Na}_{2} \mathrm{SO}_{4}, \mathrm{KCl}, \mathrm{K}_{2} \mathrm{SO}_{4}, \mathrm{MnCl}_{2}, \mathrm{MgSO}_{4}, \mathrm{CaCl}_{2}, \mathrm{Na}$ acetate, and $\mathrm{Na}$ citrate. The effect is not explainable in terms of solute pressure since amounts of sucrose with much greater solute pressures did not inhibit growth. 
An attempt was made to establish the degree to which $\mathrm{NaCl}$ might interfere with the microbiological assay. The usual experimental conditions were used to obtain a standard thiamine-response curve. Two additional experiments were arranged in which $0.02 \mathrm{M}$ or $0.05 \mathrm{M}-\mathrm{NaCl}$ was included in medium A-1. The results (Fig. 7) show some inhibition by $\mathrm{NaCl}$. The curves also show the typical thiamine responses. It would be possible to correct for electrolyte interference in microbiological assays by using a proper reference curve but it seems probable that dilution of the samples to be assayed would make the electrolyte effect unimportant.

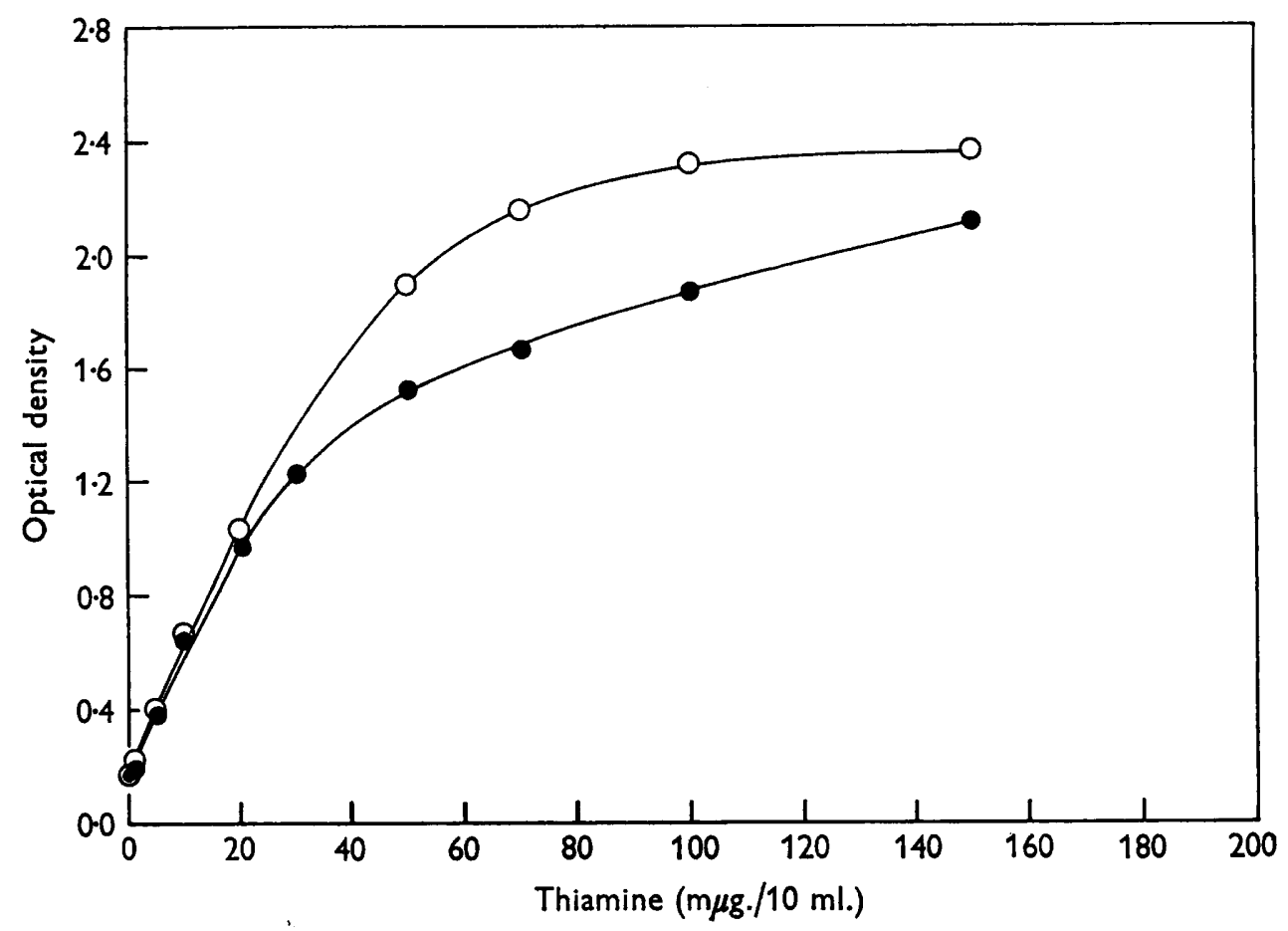

Fig. 8. Standard curve for thiamine recovery experiment using Flavobacterium aquatile as assay organism. - - actual assay curve with all constituents of medium A-1 except thiamine sterilized together. $O-O$, comparison curve showing response of $F$. aquatile to thiamine in medium A-1 compounded aseptically from sterile constituents.

\section{Microbiological assay for thiamine and thiamine recovery experiments}

Thiamine recovery experiments were arranged and the procedure given below could be used for routine measurements of thiamine. The assay medium was medium A-1; the inorganic salts, trypticase and glucose solutions were mixed; the volume brought to $90 \%(\mathrm{v} / \mathrm{v})$ of that ultimately sought, the $\mathrm{pH}$ adjusted to $7 \cdot 4$, and the medium tubed in $9 \mathrm{ml}$. amounts. Sterilization was by autoclaving at $121^{\circ}$ for $15 \mathrm{~min}$. The samples to be assayed were prepared as water extracts when the substance being tested was dry. Appropriate stock dilutions, adjusted to $\mathrm{pH} \mathbf{7 \cdot 0}$, were prepared for each material and sterilized by autoclaving. Further dilutions were prepared aseptically from the sterile stock solutions and $1 \mathrm{ml}$. of each sample dilution added to the tube assay medium. The bacterial cultures used for the 
inoculum were $24 \mathrm{hr}$. cultures which originated from similar $24 \mathrm{hr}$. cultures which had been inoculated from 7-day parent cultures held at $15^{\circ}$. All these cultures for preparing assay inocula were grown on medium M-5 agar slopes at $30^{\circ}$. Usually the growth from one slope was suspended in $2 \mathrm{ml}$. sterile water and $0.1 \mathrm{ml}$. inoculated into each assay tube. The tubes were shaken continuously during incubation for $48 \mathrm{hr}$. at $30^{\circ}$. The relative growth was read as optical density.

Thiamine concentration of the material under study was established, known amounts of thiamine added, and the microbiological assays performed. Results are shown in Table 5. The lower curve in Fig. 8 is the standard curve for reference. In

Table 5. Recovery experiments using Flavobacterium aquatile to measure known amounts of thiamine. $\mathrm{HCl}$ added to various materials

\begin{tabular}{|c|c|c|c|c|c|c|}
\hline \multirow[b]{2}{*}{ Substance } & \multirow[b]{2}{*}{ Sample no. } & \multicolumn{4}{|c|}{ Amount of thiamine. $\mathrm{HCl}$ (m $\mu \mathrm{g}$.) } & \multirow[b]{2}{*}{$\begin{array}{c}\% \\
\text { recovery† }\end{array}$} \\
\hline & & $\begin{array}{l}\text { Initially } \\
\text { present* }\end{array}$ & Added & $\begin{array}{c}\text { Total theo- } \\
\text { retically } \\
\text { present }\end{array}$ & $\begin{array}{c}\text { Total } \\
\text { assayed* }\end{array}$ & \\
\hline $\begin{array}{l}\text { Vitamin B com- } \\
\text { plex pills }\end{array}$ & $\begin{array}{l}1 \\
\mathbf{2} \\
\mathbf{3} \\
\mathbf{4} \\
\mathbf{5} \\
\mathbf{6}\end{array}$ & $\begin{array}{r}2 \\
2 \\
2 \\
14 \\
14 \\
14\end{array}$ & $\begin{array}{r}\mathbf{0} \\
\mathbf{5} \\
\mathbf{3 0} \\
\mathbf{0} \\
\mathbf{5} \\
\mathbf{3 0}\end{array}$ & $\begin{array}{r}2 \\
7 \\
32 \\
14 \\
19 \\
44\end{array}$ & $\begin{array}{r}-5 \\
31 \\
19 \\
47\end{array}$ & $\begin{array}{r}\overline{71} \\
97 \\
-100 \\
107\end{array}$ \\
\hline $\begin{array}{l}\text { Commercial } \\
\text { wheat cereal }\end{array}$ & $\begin{array}{l}1 \\
2 \\
8 \\
4 \\
5 \\
6\end{array}$ & $\begin{array}{r}\mathbf{4} \\
\mathbf{4} \\
\mathbf{4} \\
\mathbf{3 4} \\
\mathbf{3 4} \\
\mathbf{3 4}\end{array}$ & $\begin{array}{r}\mathbf{0} \\
\mathbf{5} \\
\mathbf{3 0} \\
\mathbf{0} \\
\mathbf{5} \\
\mathbf{3 0}\end{array}$ & $\begin{array}{r}\mathbf{4} \\
\mathbf{9} \\
\mathbf{3 4} \\
\mathbf{3 4} \\
\mathbf{3 9} \\
\mathbf{6 4}\end{array}$ & $\begin{array}{r}-\overline{8} \\
38 \\
-40 \\
62\end{array}$ & $\begin{array}{r}-\overline{89} \\
112 \\
- \\
108 \\
97\end{array}$ \\
\hline $\begin{array}{l}\text { Commercial } \\
\text { tomato juice }\end{array}$ & $\begin{array}{l}1 \\
2 \\
3 \\
4 \\
5 \\
6\end{array}$ & $\begin{array}{l}4 \\
4 \\
4 \\
7 \\
7 \\
7\end{array}$ & $\begin{array}{r}0 \\
10 \\
30 \\
0 \\
10 \\
30\end{array}$ & $\begin{array}{r}4 \\
14 \\
34 \\
7 \\
17 \\
37\end{array}$ & $\begin{array}{l}\overline{13} \\
35 \\
\overline{16} \\
37\end{array}$ & $\begin{array}{r}\overline{93} \\
108 \\
\overline{94} \\
100\end{array}$ \\
\hline $\begin{array}{l}\text { Commercial } \\
\text { wheat germ }\end{array}$ & $\begin{array}{l}\mathbf{1} \\
\mathbf{2} \\
\mathbf{3}\end{array}$ & $\begin{array}{l}\mathbf{5} \\
\mathbf{5} \\
\mathbf{5}\end{array}$ & $\begin{array}{r}0 \\
5 \\
40\end{array}$ & $\begin{array}{r}5 \\
10 \\
45\end{array}$ & $\begin{array}{l}- \\
10 \\
48\end{array}$ & $\begin{array}{l}- \\
100 \\
107\end{array}$ \\
\hline Human urine & $\begin{array}{l}1 \\
2 \\
\mathbf{3} \\
4 \\
5 \\
6\end{array}$ & $\begin{array}{r}\mathbf{3} \\
\mathbf{3} \\
\mathbf{3} \\
\mathbf{3 2} \\
\mathbf{3 2} \\
\mathbf{3 2}\end{array}$ & $\begin{array}{r}0 \\
5 \\
40 \\
0 \\
5 \\
40\end{array}$ & $\begin{array}{r}\mathbf{3} \\
\mathbf{8} \\
\mathbf{4 3} \\
\mathbf{3 2} \\
\mathbf{3 7} \\
\mathbf{7 2}\end{array}$ & $\begin{array}{r}-\overline{6} \\
42 \\
-36 \\
63\end{array}$ & $\begin{array}{l}\overline{75} \\
98 \\
97 \\
88\end{array}$ \\
\hline
\end{tabular}

most instances about $95 \%$ of the thiamine added was found. In two tests only were the amounts recovered appreciably less than those added, and here the total thiamine found was $8 \mathrm{~m} \mu \mathrm{g} . / 10 \mathrm{ml}$. or less. Recoveries in the range of $10-64 \mathrm{~m} \mu \mathrm{g}$. thiamine $/ 10 \mathrm{ml}$. seemed excellent. The data indicate that the error in this type of experiment probably would not exceed $\pm 10 \%$. None of the constituents of the materials tested interfered appreciably with the measurement of the thiamine added. 


\section{DISCUSSION}

Lactobacillus fermenti appears to be the most widely used organism for tube microbiological assays of thiamine. L. fermenti requires a complex basal medium and may show some vagaries in its response to thiamine. These circumstances have led to improved methods for using L. fermenti (Maciasr, 1957; Banhidi, 1958) as well as to a search for micro-organisms better suited to the microbiological assay for thiamine. Kloeckera brevis (Hoff-Jorgensen \& Hansen, 1955) offers some advantages as compared with $L$. fermenti but the basal medium required is complex, its preparation tedious in routine work, and the organism cannot be used to measure the total thiamine present in natural materials unless combined thiamine first is liberated enzymically. $L$. viridescens seems well suited to routine microbiological assays for thiamine; Deibel et al. (1957) showed that a simply and easily prepared basal medium may be used and that the growth responses to thiamine are reproducible. Also, this organism responds equally well to thiamine and to thiamine pyrophosphate. The growth responses of $L$. viridescens are related quantitatively to thiamine concentrations in the range $0-100 \mathrm{~m} \mu \mathrm{g} . / 10 \mathrm{ml}$. medium. This range of concentrations is approximately 10-fold greater than that effective for $K$. brevis (Hoff-Jorgensen \& Hansen, 1955). The growth responses of $K$. brevis and $L$. viridescens are not influenced by cultural conditions nor by the composition of basal assay media to the same extent as are the growth responses of $L$. fermenti.

The studies reported here indicate that Flavobacterium aquatile strain Taylor offers most of the advantages shown by Kloeckera brevis and Lactobacillus viridescens in microbiological assays for thiamine, and has other characteristics to recommend its use. The basal assay medium is less complex than those recommended for $K$. brevis or $L$. viridescens, especially supplements such as yeast extract are not required. No known growth factors other than thiamine need be added to the basal medium; no strains of $F$. aquatile were found which grew without added thiamine; the requirement for thiamine (or thiamine pyrophosphate) appears to be specific; the response to thiamine is reproducible; interference with the growth response to thiamine by specific compounds or those included in the natural materials studied was minimal. The concentrations of thiamine which may be measured with $F$. aquatile are comparable to those measurable by $L$. viridescens. Other useful attributes of $F$. aquatile in its use for the assay of thiamine include the ease with which the bacterium may be grown and the inocula prepared, and that the results of the assay are not critically influenced by amount of inoculum used, when the incubation period is $48 \mathrm{hr}$. Stock cultures of the bacterium may be transferred as infrequently as once a month and remain adequate sources for the inoculation of the assay media. Maximum growth responses to thiamine do require inocula prepared from stock cultures which are transferred each week. It would appear that $F$. aquatile is well suited for the measurement of the thiamine content of many natural materials.

This paper is published with the approval of the Director of the Idaho Agricultural Experiment Station as Research Paper No. 474. 


\section{REFERENCES}

BANHIDI, Z. G. (1958). Some aspects of the nutrition of Lactobacillus fermenti 36 in the tube assay of thiamine. Acta chem. scand. 12, 517.

Deibex, R. H., Evans, J. B. \& Niven, C. F. Jun. (1957). Microbiological assay for thiamine using Lactobacillus viridescens. J. Bact. 74, 818.

Frankland, G. C. \& Frankland, P. F. (1889). Über einige typische Microorganismen im Wasser und im Boden. Z. Hyg. InfektKr. 6, 373.

Hoff-Jorgensen, E. \& Hansen, B. (1955). A microbiological assay of vitamin $B_{1}$. Acta chem. scand. 9, 562.

LAURo, G. J. (1955). Polysaccharide synthesis and nutritional requirements of the species Flavobacterium aquatile (Frankland \& Frankland) Bergey et al. Thesis. University of Idaho, Moscow, U.S.A.

Litrman, M. L. (1958). Capsule synthesis by Cryptococcus neoformans. Trans. N.Y. Acad. Sci. 20,632.

MACIASR, F. M. (1957). Improved medium for assay of thiamine with Lactobacillus fermenti. Appl. Microbiol. 5, 249.

Mickelsen, O. \& Yamamoto, R. S. (1958). Methods for the determination of thiamine. In Methods of Biochemical Analysis, 6, 191. New York: Interscience Publishers.

SaretT, H. P. \& Cheldelin, V. H. (1944). The use of Lactobacillus fermentum 36 for thiamine assay. J. biol. Chem. 155, 153.

SNELl, E. E. \& WRIGHT, L. D. (1941). The microbiological method for the determination of nicotinic acid. J. biol. Chem. 139, 675.

WeEks, O. B. (1955). Flavobacterium aquatile (Frankland \& Frankland) Bergey et al., type species of the genus Flavobacterium. J. Bact. 69, 649 . 